\title{
A new approach to predict soil temperature under vegetated surfaces
}

\author{
Klaus Dolschak ${ }^{1} \cdot$ Karl Gartner $^{2} \cdot$ Torsten W. Berger $^{1}$
}

Received: 10 October 2015 / Accepted: 13 October 2015/Published online: 29 October 2015

(C) The Author(s) 2015. This article is published with open access at Springerlink.com

\begin{abstract}
In this article, the setup and the application of an empirical model, based on Newton's law of cooling, capable to predict daily mean soil temperature $\left(T_{\text {soil }}\right)$ under vegetated surfaces, is described. The only input variable, necessary to run the model, is a time series of daily mean air temperature. The simulator employs 9 empirical parameters, which were estimated by inverse modeling. The model, which primarily addresses forested sites, incorporates the effect of snow cover and soil freezing on soil temperature. The model was applied to several temperate forest sites, managing the split between Central Europe (Austria) and the United States (Harvard Forest, Massachusetts; Hubbard Brook, New Hampshire), aiming to cover a broad range of site characteristics. Investigated stands differ fundamentally in stand composition, elevation, exposition, annual mean temperature, precipitation regime, as well as in the duration of winter snow cover. At last, to explore the limits of the formulation, the simulator was applied to non-forest sites (Illinois), where soil temperature was recorded under short cut grass. The model was parameterized, specifically to site and measurement depth. After calibration of the model, an evaluation was performed, using $\sim 50 \%$ of the available data. In each case, the simulator was capable to deliver a feasible prediction of soil temperature in the validation time interval.
\end{abstract}

Klaus Dolschak

klaus.dolschak@boku.ac.at

1 Department of Forest- and Soil Sciences, Institute of Forest Ecology, University of Natural Resources and Live Sciences (BOKU), Peter Jordan-Straße 82, 1190 Vienna, Austria

2 Department of Forest Ecology and Soil, Federal Research and Training Centre for Forests, Natural Hazards and Landscape, Seckendorff-Gudent-Weg 8, 1131 Vienna, Austria
To evaluate the practical suitability of the simulator, the minimum amount of soil temperature point measurements, necessary to yield expedient model performance was determined. In the investigated case 13-20 point observations, uniformly distributed within an 11-year timeframe, have been proven sufficient to yield sound model performance (root mean square error $<0.9{ }^{\circ} \mathrm{C}$, Nash-Sutcliffe efficiency $>0.97$ ). This makes the model suitable for the application on sites, where the information on soil temperature is discontinuous or scarce.

Keywords Empirical model - Dynamical model .

Newton's law of cooling - Forest soil temperature - Freeze/ thaw transition $\cdot$ Simulated annealing

\section{Introduction}

Various biotic, as well as abiotic processes in the soil are temperature dependent (Rankinen et al. 2004). Usually, these dependencies are assumed to have a non-linear nature (Bond-Lamberty et al. 2005; Davidson et al. 2006; Macdonald et al. 1995; Wagle and Kakani 2014), meaning that the response of the process to changes of temperature, strongly depends on the temperature range it is occurring in. Especially for high temperatures, small changes in temperature might yield big changes in the processes response. For the assessment of temperature dependent soil processes, it is therefore crucial to have expedient knowledge about spatial, as well as temporal fluctuations of soil temperature (Bond-Lamberty et al. 2005). The most reliable source of information would be the permanent monitoring of subsurface ground temperature. But in practice it is often hard to measure continuously. Usually, the modeler has to deal with fragmentary timelines of soil temperature, 
scarce point observations or even no records of $T_{\text {soil }}$ at all (Lei et al. 2011). To fill these gaps or to extend the timeline beyond the measurement timeframe, the researcher has to consider the application of a soil temperature model.

The approaches to predict subsurface ground temperature can be coarsely divided in 2 categories; (1) process based models, and (2) empirical models (Kang et al. 2000). Process based approaches to predict soil temperature generally use meteorological input variables (primarily temperature and solar radiation) to calculate energy balance of the soil surface, and heat transport in the soil, by solving the heat equation (Paul et al. 2004). The applicability of these models is often limited by their high complexity, high demand of input data, and specific model parameters, which are often not available for the investigated site (Lei et al. 2011; Svensson et al. 2008). Empirical models, presented in the work of Brown et al. (2000), Kang et al. (2000), or Paul et al. (2004), rely on the statistical relationship between meteorological parameters and soil temperature. More recently, there have been successful attempts to predict $T_{\text {soil }}$ using combinations of artificial neural networks and fuzzy logic (Bilgili et al. 2013; Kim and Singh 2014; Kisi et al. 2015; Talaee 2014).

Soil thermal regimes are controlled by various environmental drivers. The most important meteorological factors are air temperature and radiation, laying the base for heat exchange at the soil surface (Hu and Feng 2003). In the latter, forested sites differ substantially from other types of land-cover: The radiation driven heat exchange between soil surface and atmosphere, is limited due to the shielding effect of the canopy (Paul et al. 2004). Therefore, forested sites show strongly dampened $T_{\text {soil }}$ fluctuations, compared to sites with sparse vegetation or bare soil (Balisky and Burton 1993). Only a few models exist, which explicitly address the soil thermal conditions of forested ecosystems.

Zheng et al. (1993) set up a dynamical $T_{\text {soil }}$ model based on Newton's law of cooling, assuming the change of $T_{\text {soil }}$ proportional to the temperature difference between air and soil. The fact, that the vegetation cover limits radiation driven heat flux, is taken into account by utilizing a heat transfer coefficient, which depends on the stands leaf area. They assume, that the canopy's damping effect is more pronounced for incoming radiation, than for emission from the ground. This is incorporated, by applying different heat transfer coefficients, whether the soil is warming or cooling. The damping term, dependent on LAI, only comes into effect for soil warming conditions. Based on this work, Kang et al. (2000) set up a spatially resolved $T_{\text {soil }}$ model. To describe the soil thermal regimes of South Korean forest sites, they extended the latter approach by introducing a more 'mechanistic' element, based on Fourier's law of heat transport. Besides the spatial and temporal variability of the leaf area, this approach also accounts for the effect of the stands litter layer on soil heat flux. The authors assumed, that $T_{\text {soil }}$ does not fall below freezing for most Korean forest sites. As well as in the latter approach, $T_{\text {soil }}$ estimates below $0{ }^{\circ} \mathrm{C}$ were replaced with $0{ }^{\circ} \mathrm{C}$.

Brown et al. (2000), predicted daily mean $T_{\text {soil }}$ of 4 different Northern Hardwood stands, utilizing a statistical relationship between $T_{\text {soil }}$ and the average air temperature of the previous day. As a correction term, accounting for the phase shift or 'lagging behind' of the annual course of $T_{\text {soil }}$ compared to air temperature, they introduced a cosine function of the Julian day. Despite the simple model structure, the predictions of $T_{\text {soil }}$ were quite precise (disregarding the cold season).

To predict daily $T_{\text {soil }}$ of various Australian forest sites, Paul et al. (2004) used daily average air temperature and stand parameters like leaf area, understory growth, and litter mass. They assumed $T_{\text {soil }}$ oscillating around an annual mean soil temperature, which is calculated from annual mean air temperature, modified with a correction factor, derived from information about the stands' vegetation cover and litter layer. The resulting temperature wave is then offset by a term describing daily fluctuations of $T_{\text {soil }}$, which again, is derived from air temperature. The model specifically addresses the thermal conditions of the topsoil. Therefore, phase shift and attenuation of the temperature oscillation, which become relevant with increasing soil depth, were not considered.

Bond-Lamberty et al. (2005) examined the spatiotemporal dynamics of soil thermal regimes during stand development of a disturbed boreal forest. To accompany this investigation and for laying the base to simulate forest dynamics, they implemented an empirical $T_{\text {soil }}$ model. Accounting for the influence of recent past air temperature conditions on present $T_{\text {soil }}$, they calculate running averages of the daily mean air temperature. $T_{\text {soil }}$ is then calculated as a linear function of multiple running averages, centered to different days in the past. The authors report difficulties to predict $T_{\text {soil }}$ close to the freeze/thaw transition.

To evaluate the suitability of $T_{\text {soil }}$ as a predictor for the treeline position in the Swiss Alps, Gehrig-Fasel et al. (2008) presented an approach, which strongly differs from others described in this section. To satisfy the statistical requirements for regression modeling, the data was first detrended and then transformed for first differences. After performing the regression analysis, the data was transformed back. Considering that daily mean air temperature was the only input parameter, the model showed high performance in the validation timeframe. Assuming only an insignificant influence of winter soil temperatures on the treeline position (Körner and Paulsen 2004), the validation could be limited to the warm season. 
Most approaches presented here disregard $T_{\text {soil }}$ dynamics of the cold season. The decoupling of the soil from the atmosphere by a fluctuating snowpack (Betts et al. 2001), the heat transformation processes at the phase change from liquid to frozen (Beltrami 2001; Viterbo et al. 1999), or changes in heat capacity and conductivity seem difficult to be captured in the framework of an empirical approach. In cases where winter $T_{\text {soil }}$ is assumed to reach or fall below $0{ }^{\circ} \mathrm{C}$, process based approaches, presented by e.g. Rankinen et al. (2004), should be preferred. But, even though this model could be described 'simple' from a mechanistic point of view, solely the empirical snow accumulation/melt module, upstream to the $T_{\text {soil }}$ model, requires the assignment of 11 free parameters. An alternative might be the semi-empirical model presented by Katterer and Andren (2009). Making the approach suitable for colder temperature conditions, the formulation presented by Kang et al. (2000) was modified. They interposed a surface temperature term, which acts as link between air and soil temperature. In this term the influence of air temperatures below $0{ }^{\circ} \mathrm{C}$ is attenuated by a constant factor. This way, they account for the low thermal conductivity of snow.

The objective of this article is the presentation of a model to predict soil temperature of forest stands, which aims to perform like a 'well-tuned' mechanistic simulator, using the straightforwardness of an empiric formulation. The model enables the transformation of fragmentary records of forest soil temperature, into a complete time series of $T_{\text {soil }}$, using average daily air temperature as only input. In this specific case, the created time series is laying the base for the modeling of temperature dependent, biogeochemical soil processes. Due to the fact that many biotic soil processes are sensitive to winter conditions (Campbell et al. 2005), emphasis is laid on an expedient representation of the temperature dynamics of the cold season.

Running the simulation requires the adjustment of nine empirical parameters, which are not defined in a strict physical sense. This is making it hard to deduce parameter values directly from site information. For a proper site specific parameterization, at least some snapshot measurements of $T_{\text {soil }}$ are recommended. Therefore, this model primarily aims to sites were $T_{\text {soil }}$ data is available, but the time series are inconsistent, or have to be extended beyond the timeframe of measurement.

\section{Materials and methods}

\section{Model description}

The model describes $T_{\text {soil }}$ as a function of daily mean air temperature $\left(T_{\mathrm{air}, t}\right)$. It employs a daily time step. The formulation is based on Newton's law of cooling (Bergman et al. 2011), which is applied 2 times consecutively.
Utilizing a relatively small heat transfer coefficient ( $\lambda_{\text {shift }}$ ), the first application of Newton's law provides a phase shifted temperature time series $\left(T_{\text {shift, } t}\right)$ which lacks the high frequency fluctuations of $T_{\mathrm{air}, t}$.

$T_{\text {shift }, t}=T_{\text {air }, t}+\left(T_{\text {shift }, t-1}-T_{\text {air }, t}\right) \exp \left(-\lambda_{\text {shift }}\right)$

A fictive environmental temperature $\left(T_{\text {env }, t}\right)$ is postulated as the weighted mean of the elements $T_{\mathrm{air}, t}, T_{\mathrm{shift}, t}$, and a constant correction temperature $\left(T_{\text {corr }}\right) . p c_{\text {air }}, p c_{\text {shift }}$, and $p c_{\text {corr }}$ are partitioning coefficients, which define the relative weight of the specific element.

$T_{\text {env }, t}=T_{\text {air }, t} p c_{\text {air }}+T_{\text {shift }, t} p c_{\text {shift }}+T_{\text {corr }} p c_{\text {corr }}$

The partitioning coefficients sum up to 1 , so 2 have to be defined as model parameters, one can be deduced.

$p c_{\text {corr }}=1-\left(p c_{\text {air }}+p c_{\text {shift }}\right)$

$\Delta T$ states the difference of the soil temperature to $T_{\text {env, } t}$.

$\Delta T=T_{\mathrm{env}, t}-T_{\mathrm{soil}, t-1}$

Taking into account the insulating effect of the snow cover and the heat release/consumption due to the phase change of soil water from liquid to solid and vice versa (Beltrami 2001), a variable heat transfer coefficient $\left(\lambda_{\text {eff }}\right)$ is implemented (Fig. 1). $\lambda_{\max }$ represents the transfer coefficient above the upper threshold temperature $\left(T_{1}\right)$. Below $T_{1}$ $\lambda_{\text {eff }}$ gets reduced, reaching the minimum $\left(\lambda_{\min }\right)$ at the lower threshold $\left(T_{0}\right)$, where different $\lambda_{\min }$ are applied for soil warming and cooling.

$\lambda_{\text {min }}= \begin{cases}\lambda_{\text {thaw }}, & \Delta T>0 \\ \lambda_{\text {frost }}, & \Delta T \leq 0\end{cases}$

The transition of the transfer coefficient in between $T_{1}$ and $T_{0}$ is described, using a third order polynomial.

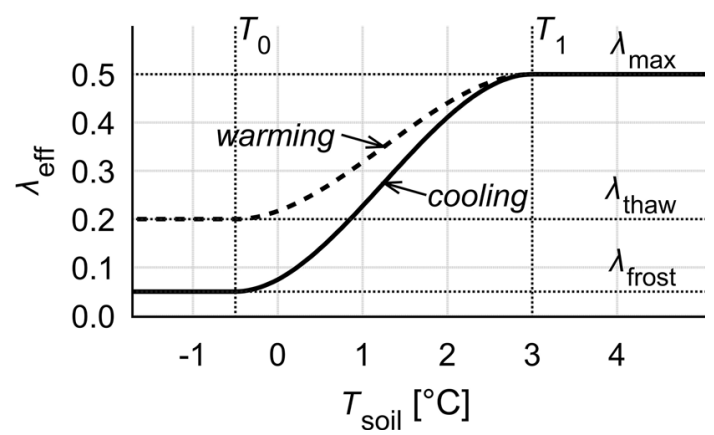

Fig. 1 Polynomial transition of the heat compensation coefficient $\left(\lambda_{\text {eff }}\right)$, between 2 threshold soil temperatures $\left(T_{0}, T_{1}\right)$, close to soil freezing. The reduction of the coefficient pays respect to the energy release/demand of phase changes, from liquid to solid and vice versa. High model performance was achieved, using different minimal compensation coefficients for soil cooling $\left(\lambda_{\text {frost }}\right)$ (solid line) and warming $\left(\lambda_{\text {thaw }}\right)$ (dashed line) respectively 
$\lambda_{\text {eff }}= \begin{cases}\lambda_{\min }, & T_{\text {soil }, t-1} \leq T_{0} \\ \lambda_{\min }+\left(\lambda_{\text {max }}-\lambda_{\text {min }}\right)\left(3 x^{2}-2 x^{3}\right), & T_{0}<T_{\text {soil }, t-1}<T_{1} \\ \lambda_{\max }, & T_{\text {soil }, t-1} \geq T_{1}\end{cases}$

$T_{\text {soil, } t-1}$ has to be transformed into an auxiliary variable inside the interval $0-1$.

$x=\frac{T_{\text {soil }, t-1}-T_{0}}{T_{1}-T_{0}}$

At last, Newton's law is applied the 2nd time. The actual daily mean soil temperature calculates as:

$T_{\text {soil }, t}=T_{\text {env }, t}-\Delta T \exp \left(-\lambda_{\text {eff }}\right)$

\section{Study sites/input data}

\section{Austria}

In the framework of the International Co-operative Programme on Assessment and Monitoring of Air Pollution Effects on Forests (ICP Forests), the Austrian Research Centre for Forests operates several, intensively monitored, forest sites (Level II) (Neumann et al. 2001). In addition to various other environmental parameters, meteorological conditions are monitored continuously. Soil temperature records exist for soil depths, ranging from 5 to $60 \mathrm{~cm}$.

The model was originally set up on data from the Level II Plot Klausen-Leopoldsdorf, which is located in the Vienna Woods $\left(48^{\circ} 07^{\prime} 16^{\prime \prime} \mathrm{N}, 16^{\circ} 02^{\prime} 52^{\prime \prime} \mathrm{E}\right)$, at an elevation of $510 \mathrm{~m}$ a. s. 1. The research site is a pure beech (Fagus sylvatica $\mathrm{L}$.) stand, which was planted in the late thirties of the last century. The location is facing NE with an inclination of $20 \%$. The actual forest vegetation coincides with the potential natural one, and can be classified as Hordylemo-Fagetum (Mucina et al. 1993).

Subsequently data from 5 other Level II forest stands were accessed (Fig. 2, Table 1). The selection aims to cover a broad range of site characteristics. Investigated sites show a strong altitudinal and climatic gradient. The elevation of the investigated stands ranges from 290 (Unterpullendorf) to $1540 \mathrm{~m}$ a.s.l. (Murau), leading to annual mean temperatures from 9.6 to $5{ }^{\circ} \mathrm{C}$, respectively. Austria lies in the transition zone between oceanic and continental climate. Progressing from west to east, investigated locations therefore experience a strong decline in annual precipitation sums, ranging from $1521 \mathrm{~mm}$ for mountainous stands in the north-west, affected by orographic precipitation (Mondsee), to $630 \mathrm{~mm}$ in the continentally influenced east of the country (Unterpullendorf).

To fill gaps in the record of average daily air temperature, data were accessed, provided by the European Climate Assessment (ECA\&D) (Tank et al. 2002). Missing values were replaced, using linear regression with available neighboring stations.

\section{East Coast of the United States}

Intending to test the models over regional validity, the continent was switched. Data were accessed from 2

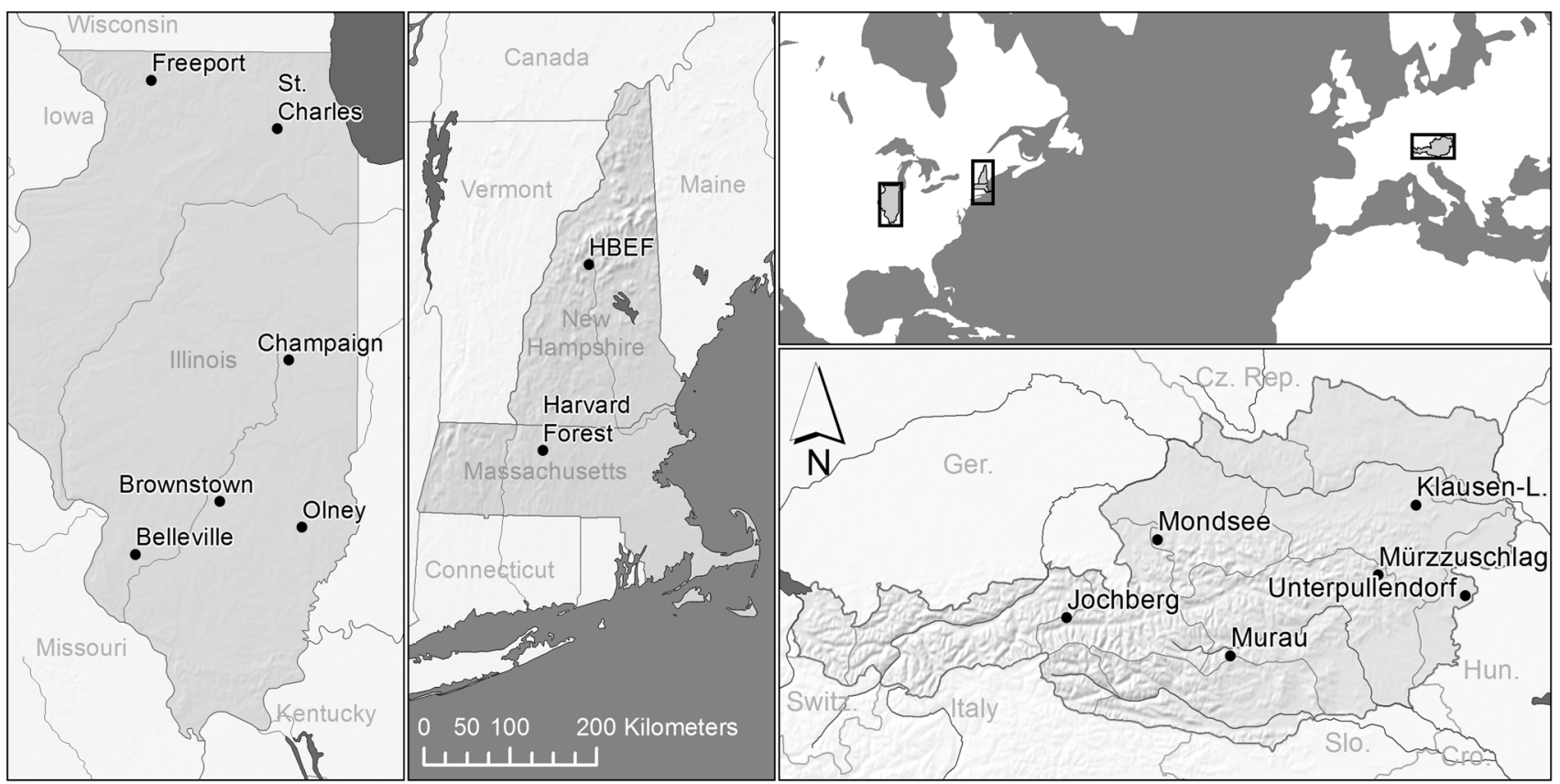

Fig. 2 Location of study sites in the United States and in Austria. The sites used for parameterization of the forest soil temperature simulator cover a broad range of characteristics. For a brief site description see Table 1 
Table 1 Investigated locations cover a broad range of site characteristics and distinct climatic and altitudinal gradients

\begin{tabular}{|c|c|c|c|c|c|c|c|c|}
\hline & & $\begin{array}{l}\text { Elevation } \\
\text { (m a. s. 1.) }\end{array}$ & Exp. & Slope $\left(^{\circ}\right)$ & $\operatorname{MAT}\left({ }^{\circ} \mathrm{C}\right)$ & MAP (mm) & Dominant species & Soil type \\
\hline \multirow[t]{6}{*}{ Level II } & Jochberg & 1050 & NE & 4 & 5.7 & 1358 & Picea abies & Dystric Cambisol \\
\hline & Mondsee & 860 & SE & 14 & $\sim 5.7$ & 1521 & Picea abies & Eutric Cambisol \\
\hline & Murau & 1540 & $\mathrm{~N}$ & 33 & 5.0 & 918 & Picea abies & Dystric Cambisol \\
\hline & Mürzzuschlag & 715 & $S$ & 10 & 6.0 & 933 & Picea abies & Eutric Cambisol \\
\hline & $\begin{array}{l}\text { Klausen- } \\
\text { Leopoldsdorf }\end{array}$ & 510 & NE & 11 & 8.2 & 804 & Fagus sylvatica & Stagnic Cambisol \\
\hline & Unterpullendorf & 290 & - & 0 & 9.6 & 630 & Quercus petraea/cerris & Planosol \\
\hline \multirow[t]{2}{*}{ HBEF } & High Elevation Plots & 560 & $\mathrm{~N}$ & $\sim 13$ & 5.0 & 1400 & Betula alleghaniensis & Podzol \\
\hline & Low Elevation Plots & 430 & $S$ & $\sim 11$ & 6.1 & 1400 & Acer saccharum & Podzol \\
\hline \multirow[t]{2}{*}{ Harvard Forest } & Prospect Hill & 365 & - & 0 & 8.5 & 1080 & Quercus rubra & Dystric Cambisol \\
\hline & Barre Woods & 305 & - & 0 & 8.5 & 1080 & Quercus rubra/velutina & Dystric Cambisol \\
\hline \multirow[t]{6}{*}{ ICN } & Freeport & 265 & - & 0 & $\sim 9.1$ & $\sim 860$ & Sod covered ground & \\
\hline & St. Charles & 226 & - & 0 & $\sim 9.3$ & $\sim 780$ & Sod covered ground & \\
\hline & Champaign & 219 & - & 0 & $\sim 11.3$ & $\sim 1020$ & Sod covered ground & \\
\hline & Belleville & 133 & - & 0 & $\sim 12.7$ & $\sim 960$ & Sod covered ground & \\
\hline & Brownstown & 177 & - & 0 & $\sim 12.3$ & $\sim 960$ & Sod covered ground & \\
\hline & Olney & 134 & - & 0 & $\sim 12.5$ & $\sim 1010$ & Sod covered ground & \\
\hline
\end{tabular}

MAT mean annual temperature, MAP mean annual precipitation sum

intensive long-term ecological research areas in New England; (1) the Hubbard Brook Experimental Forest (HBEF), and (2) Harvard Forest (Fig. 2, Table 1).

The HBEF is located in the White Mountain National Forest in north-central New Hampshire $\left(43^{\circ} 56^{\prime} \mathrm{N}\right.$, $\left.71^{\circ} 42^{\prime} \mathrm{W}\right)$. The elevation of the investigated watershed ranges from $250 \mathrm{~m}$ to $1000 \mathrm{~m}$. The forest type can be classified as Northern Hardwood, dominated by Sugar maple (Acer saccharum Marsh). The climate is cool, continental, and humid, with mean annual precipitation sums around $1400 \mathrm{~mm}$ (Bailey et al. 2003). Approximately onethird of the precipitation is falling as snow, leading to a snowpack, typically lasting from December to April. Soils can be classified as well-drained Spodosols (WRB: Podzol), developed on glacial till (Campbell et al. 2010).

Daily $T_{\text {soil }}$ (depth: $5 \mathrm{~cm}$ ) data, recorded within the framework of the project 'Snow Depth \& Soil Freezing as a Regulator of Microbial Processes' (Duran et al. 2014), were obtained. Data of 3 intensive high elevation plots (mean elevation: $560 \mathrm{~m}$, exposition: North) and 3 intensive low elevation plots (mean elevation: $430 \mathrm{~m}$, exposition: South) were used. For each altitude class, one mean timeseries of $T_{\text {soil }}$ was calculated.

Because of their proximity to the investigated stands, records of air temperature (Bailey et al. 2003) from meteorological station 23 and 1, for high and low elevation plots respectively were obtained. Missing data were replaced, using offset temperatures of highly correlated neighboring stations. To fill remaining gaps in the air temperature record, the GHCN-Daily dataset was accessed, provided by the NOAA (Menne et al. 2012a, b), utilizing data from the station Wentworth, New Hampshire (435 $\left.52^{\prime} 22^{\prime \prime} \mathrm{N}, 71^{\circ} 54^{\prime} 31^{\prime \prime} \mathrm{W}\right)$.

The Harvard Forest Research Station is located in Central Massachusetts $\left(42^{\circ} 32^{\prime} \mathrm{N}, 72^{\circ} 11^{\prime} \mathrm{W}\right)$. The climate is cool, temperate, and humid. Precipitation is distributed evenly through the year, with annual sums in the range of $1080 \mathrm{~mm}$. The annual mean temperature is $8.5^{\circ} \mathrm{C}$ (Berbeco et al. 2012). The elevation of the investigated locations is approximately $350 \mathrm{~m}$ a. s. 1. Soils can be classified as Typic Dystrudepts (WRB: Dystric Cambisol). After a severe disturbance in the beginning of the last century, the forest regrew naturally, resulting in an even aged stand of mixed hardwood species, with Red oak (Quercus rubra L.) dominating (Butler et al. 2012).

Within the forest site, the simulator was applied to 2 sub-sites: (1) Barre Woods (Melillo et al. 2003), and (2) Prospect Hill (Melillo et al. 1999). Both locations were set up to study the effect of soil warming on carbon and nitrogen turnover, by artificially heating the ground (Berbeco et al. 2012; Melillo et al. 2002). The model was adjusted to the topsoil (depth $5 \mathrm{~cm}$ ) of the undisturbed control plots, whereat on the Prospect Hill site data from 6 control plots were combined, calculating a mean timeseries of $T_{\text {soil }}$. Daily air temperature was obtained from the EMS tower (Munger and Wofsy 1999), where the record $7.6 \mathrm{~m}$ above ground was selected. Data gaps were closed, using offset temperature measurements at other heights, or 
data from the Fisher meteorological station (Boose 2001). If no other source was available, the GHCN-Daily dataset was again accessed, applying offset air temperature data from the Municipal Airport station at Orange, Massachusetts $\left(42^{\circ} 33^{\prime} 46^{\prime \prime} \mathrm{N}, 72^{\circ} 16^{\prime} 59^{\prime \prime} \mathrm{W}\right)$.

\section{Non-forested sites in Illinois}

At last, to explore the limits of the formulation, the model was applied to 6 sites which lack the shielding properties of a dense forest canopy. Therefore, data were obtained from the Illinois Climate Network, (ICN), which operates several open field meteorological stations in Illinois (Fig. 2, Table 1). Air temperature was measured $2 \mathrm{~m}$ above ground. Gaps in the air temperature record were closed, using offset temperature measurements of, highly correlated, and neighboring stations. Soil temperature was recorded in $10 \mathrm{~cm}$ and $20 \mathrm{~cm}$ depth (Hollinger et al. 1994) under sod covered ground. Soil texture was assessed as silt loam, throughout all studied locations. The elevation of the investigated sites ranges from 133 to $265 \mathrm{~m}$ a. s. 1 .

Illinois' climate is typically continental with cold winters and warm summers. Moving from north to south, mean annual air temperatures increase from 8.9 to $14.5^{\circ} \mathrm{C}$. Also annual precipitation sums reveal a strong north-south gradient, ranging from 810 to $1220 \mathrm{~mm}$. Stations in the north-west of the state are climatically influenced by Lake Michigan, which is attenuating temperature extremes and enhancing winter precipitation (lake effect snow) (Changnon et al. 2008).

\section{Model application}

\section{Parameterization}

The model was applied to each site and depth specifically. Emphasis was laid on its application on longest possible records of $T_{\text {soil }}$, to cover the broadest possible range of different environmental states, which might have a potential influence on soil thermal regimes. On the other hand it seems obvious, that due to changes in leaf area, undergrowth, litter layer, water consumption, etc., forest $T_{\text {soil }}$ regimes undergo a certain shift during stand development (compare Kang et al. 2000). In cases where, for reasons unknown, an obvious change in the soil thermal regime was observed, the time frame of the investigation was manually narrowed down. Both $T_{\text {soil }, t}$ and $T_{\text {shift, } t}$ were initialized at $8{ }^{\circ} \mathrm{C}$. The simulator ran a 150 day spin-up prior to the analysis time frame. For model parameterization a simulated annealing algorithm (Kirkpatrick et al. 1983) was applied, selecting an exponential cooling schedule. Optimization/evaluation criterion was in every case the NashSutcliffe model efficiency (NSE) (Nash and Sutcliffe 1970).
$N S E=1-\frac{\sum_{i=1}^{n}\left(T_{\text {soil }, o b s, i}-T_{\text {soil }, \text { sim }, i}\right)^{2}}{\sum_{i=1}^{n}\left(T_{\text {soil }, o b s, i}-\bar{T}_{\text {soil }, o b s}\right)^{2}}$

Enabling a balanced split, the calibration was conducted on data from odd years, data from even years served in the evaluation. Making the simulation result comparable to other works, other performance indices like Root Mean Squared Error (RMSE), mean absolute error (MAE) and mean bias error (MBE) were calculated.

$\boldsymbol{R M S E}=\left[\boldsymbol{n}^{-1} \sum_{i=1}^{n}\left(\boldsymbol{T}_{\text {soil }, \text { obs }, i}-\boldsymbol{T}_{\text {soil }, \text { sim }, i}\right)^{2}\right]^{1 / 2}$

$M A E=n^{-1} \sum_{i=1}^{n}\left|T_{\text {soil }, o b s, i}-T_{\text {soil }, \text { sim }, i}\right|$

$M B E=n^{-1} \sum_{i=1}^{n} T_{\text {soil }, o b s, i}-T_{\text {soil }, \text { sim }, i}$

\section{Parameterization on limited input data}

To test the simulators practical suitability to cope with limited input data, the $T_{\text {soil }}$ record of Klausen Leopoldsdorf $(15 \mathrm{~cm}$ depth) was used, ranging from November 2001 to June 2013 ( $\sim 11$ years, 4053 valid observations). The dataset was split into $n$ sectors of approximately equal size. The parameterization (simulated annealing) was performed, drawing only one random observation per sector. The remaining observations served in the evaluation. This step was repeated 12 times per $n$, each time with different random observations, to generate a distributed result. After 12 iterations, $n$ was incremented, starting with $n=4$, gradually progressing to $n=2000$. This way, the minimum number of point observations was determined, necessary to yield satisfactory model performance.

\section{Results and discussion}

The model was applied to various sites and depths. In this work, a representative selection of 36 simulation runs is displayed (Table 2). The simulator delivered good estimates of $T_{\text {soil }}$ on all investigated forest sites. NSE values above 0.979 and RMSE consistently below $1{ }^{\circ} \mathrm{C}$ underline the outcome (Table 3), whereat good results were not limited to the topmost soil horizons. Increasing phase shift and the attenuation of the temperature wave with increasing soil depth, were also captured by the simulation (Fig. 3b). Winter $T_{\text {soil }}$ dynamics are strongly affected by (1) heat transformations at the freeze/thaw transition and (2) the insulating by the snowpack (Beltrami 2001). The 
Table 2 Parameterization result for 36 sites and depths

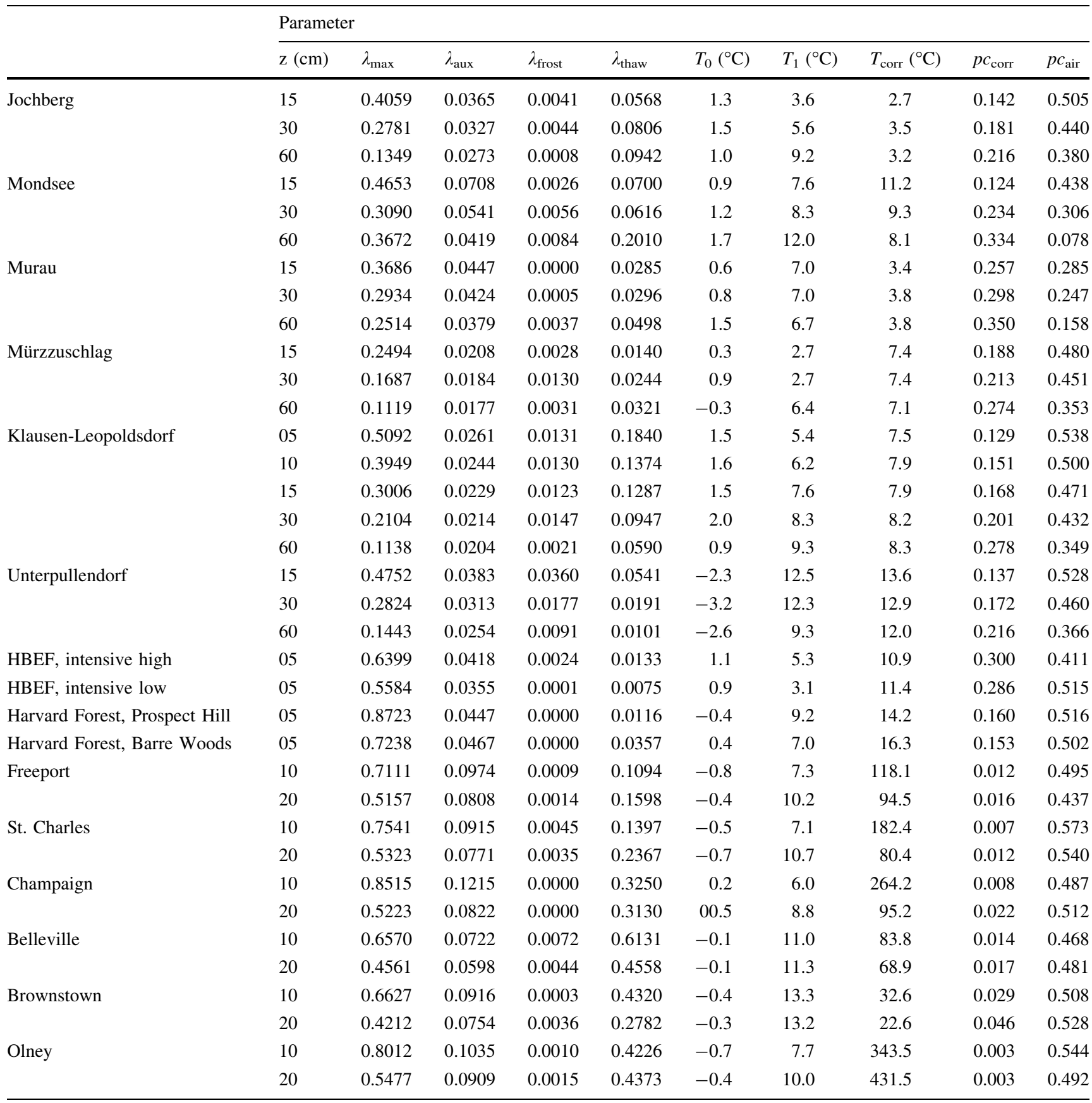

Optimization was performed, using a simulated annealing algorithm. Performance criterion was the Nash-Sutcliffe Efficiency (NSE)

presented model does not specifically address these effects, but it is capable, to account for both effects combined. In most cases, the description of the winter soil thermal regime was successful. Figures 3a, d and 4a clearly show the decoupling of ground temperature from air temperature under snow cover. The simulator was able to track this behavior, where in some cases it failed to predict the exact time when soil temperature rises in spring (Fig. 4a): The melting of the snow cover causes a sharp increase in $T_{\text {soil }}$ due to the ceasing insulating effect, hand in hand with an abrupt decrease in surface albedo, making the forest ground susceptible for short wave radiation inputs, which are already considerable in early spring. Rankinen et al. (2004) solved this problem by incorporating a snow dynamics routine into the calculations, but this would require the embedding of more model parameters and meteorological input data. In consideration of the models practical applicability, this was set aside. 


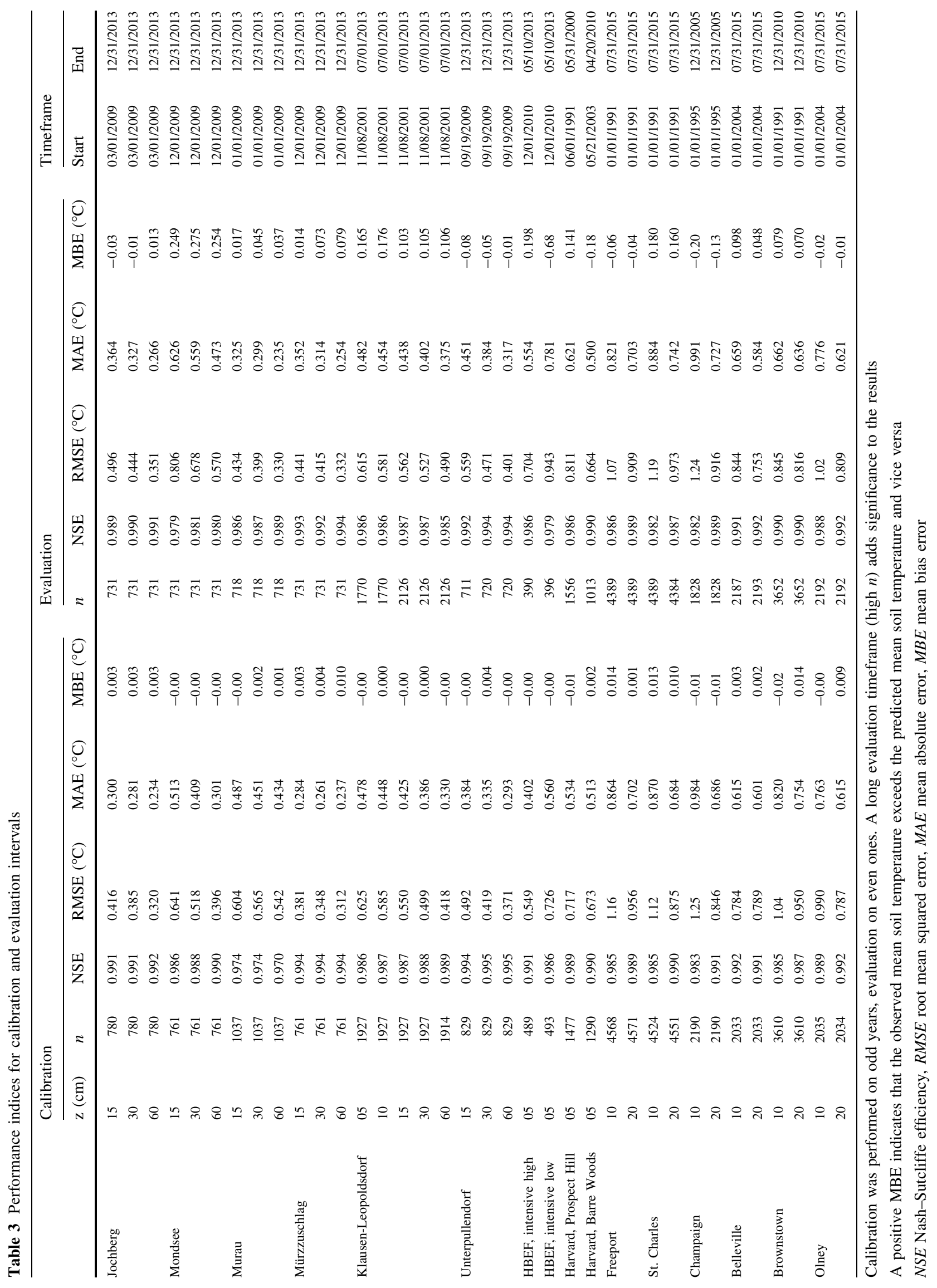



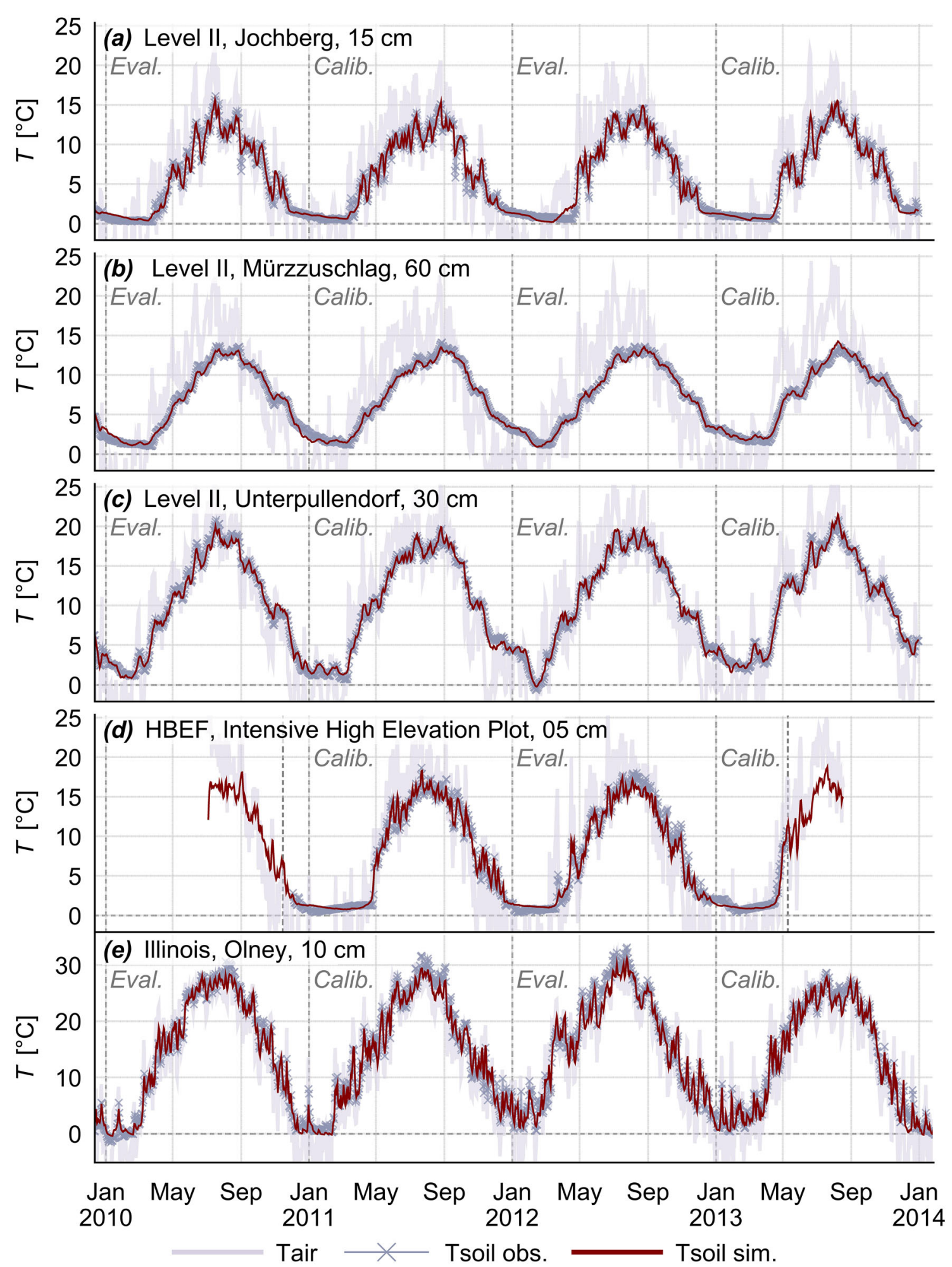

Fig. 3 Four years of observed air and soil temperature, overlaid with simulated $T_{\text {soil. }}$. Calibration was performed on odd years, performance evaluation on even ones. Plot (a) and (d) clearly show the effect of snow cover on winter soil thermal regimes. In both cases the trend was successfully captured by the simulator. Also increasing phase shift and attenuation of the soil temperature wave with increasing soil depth (b) were captured. Stronger fluctuations of $T_{\text {soil }}$ under openfield conditions (e), where the heat exchange might be dominated by radiation fluxes, did also not limit the simulators capability 

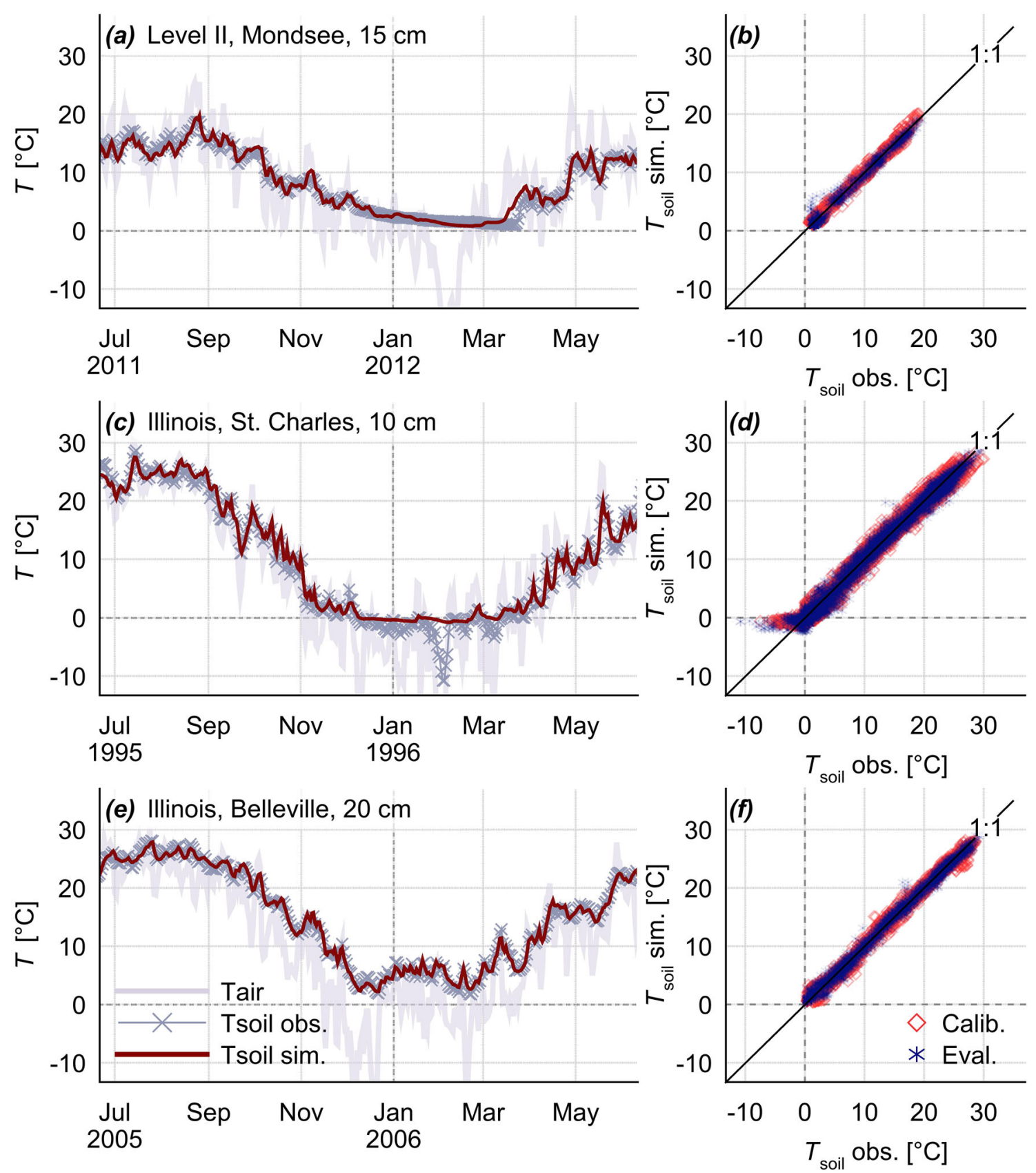

Fig. 4 One year section of observed and simulated $T_{\text {soil }}$ time series plus the corresponding performance scatterplot. Note that the scatterplots cover the whole investigation timeframe! (a, b) winter snow cover decouples the course of air and soil temperature. The melting of the snowpack in the end of March causes $T_{\text {soil }}$ to escalate, due to the ceasing insulation plus the abrupt decrease in surface albedo, making the soil susceptible for short wave radiation inputs, which are already considerable in early spring. As the snowpack is not modeled explicitly, the simulator fails to predict the exact time when

Compared to forested locations, the biotic site components at the open field meteorological stations are kept intentionally constant. This enabled the successful prediction of $T_{\text {soil }}$ over a long timeframe. On 2 sites in the
$T_{\text {soil }}$ rises in spring $(\mathbf{c}, \mathbf{d})$. Failure to predict a major soil frost event, due to limitations in the model structure: Temperature fluctuations in early winter indicate the absence of a snow pack. When in midwinter all latent heat is released due to the freezing of soil water, $T_{\text {soil }}$ suddenly drops. In the formulation the transfer coefficient below the lower threshold temperature $\left(T_{0}\right)$ remains constant. As a consequence, our formulation applies best, to sites where severe soil frost plays only a subordinate role $(\mathbf{e}, \mathbf{f})$

northern part of the state (Freeport, St. Charles) we accomplished good results over 24 years of calibration and evaluation. But the best performance (evaluation NSE $\geq 0.99$ over several years) was achieved on comparatively 
Fig. 5 Model optimization result for Klausen-

Leopoldsdorf, $15 \mathrm{~cm}$ : to determine the amount of point observations, necessary to achieve sound model performance, the investigated time series was divided into $n$ intervals of equal size, drawing one random point observation each. These $n$ observations were used to optimize the model (simulated annealing). The remaining observations were used to validate model performance. For each $n$, the procedure was repeated 12 times with different random observations, to generate a distributed result. Performance measures shown are (a) root mean squared error, and (b) Nash-Sutcliffe efficiency. Both indices show high performance

$\left(\mathrm{RMSE}<0.9{ }^{\circ} \mathrm{C}, \mathrm{NSE} \geq 0.97\right)$ with $n \geq 13$. For $n \geq 50$ there was only little difference in performance, compared to optimization utilizing the full calibration timeframe $(n=2000$, horizontal, grey line)
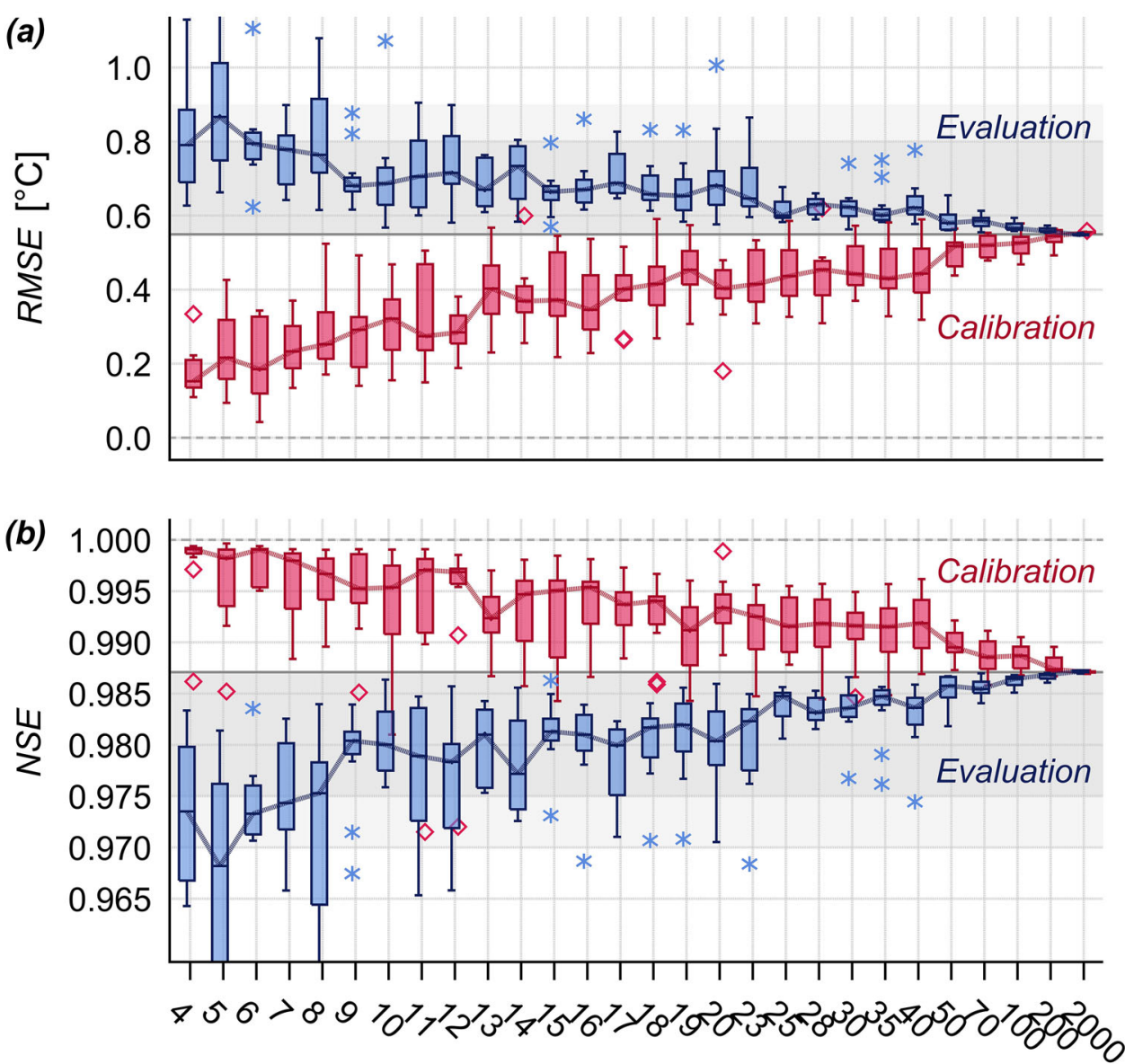

Number of point observations used in calibration ( $n$ ) warm locations, located at low elevations, in the south of Illinois (Belleville, Brownstown, Olney). In contrast to forested sites, open field sites, lack the attenuating properties of a dense canopy, or a thick litter layer. Especially for cold, but snow-free winters, these locations were prone to soil frost (Fig. 4c, St. Charles). Temperature fluctuations in early winter indicate the absence of a thick insolating snow pack. When in midwinter all latent heat is released, due to the freezing of soil water, $T_{\text {soil }}$ suddenly drops. Due to the structure of the model, this behavior could not be tracked: In the presented formulation the transfer coefficient below the lower threshold temperature $\left(T_{0}\right)$ remains constant at a reduced level, suppressing further soil cooling. This model limitation could be tackled by letting the transfer coefficient rise at temperatures below $T_{0}$. On the other hand, that would require the segregation of the effects of freeze/thaw processes and snow cover insulation, making the model again more complex and input data demanding.

The examination, to determine the minimum amount of point observations of soil temperature, necessary to yield suitable results, was performed on, an 11-years time series, of air and soil temperature at the Level II plot KlausenLeopoldsdorf (15 cm depth). The time frame was divided in $n$ sectors. Only one observation was selected randomly by sector. All other observations served in the evaluation. Disregarding single outlier runs, good results (NSE >0.97, RMSE $<0.9^{\circ} \mathrm{C}$ ) were achieved with $n \leq 13$. Having available 50 or more daily observations, there was only little difference to the result, compared to utilizing $\sim 50 \%(n=2000)$ of the available data in the calibration process (Fig. 5).

Two considerations led to the implementation of decreasing transfer coefficients with decreasing soil temperature: (1) The heat release/consumption at the freeze/ thaw transition (Beltrami 2001), and (2) the insulating effect of the winter snow cover. So intentionally, values for $T_{0}$ and $T_{1}$ were searched around $0{ }^{\circ} \mathrm{C}$. Surprisingly, in most cases the optimization process led to $T_{1}$ values much higher, meaning that the attenuation of the transfer coefficient starts already at higher temperatures. The idea behind utilizing different responses for soil warming and cooling, was the assumption, that soil warming in spring is strongly driven by incoming solar radiation, which is accelerating the temperature rise.

As this model is primarily of an empirical nature, used parameters lack a specific meaning, in a strict physical sense. Nevertheless, it was noted that parameter values 

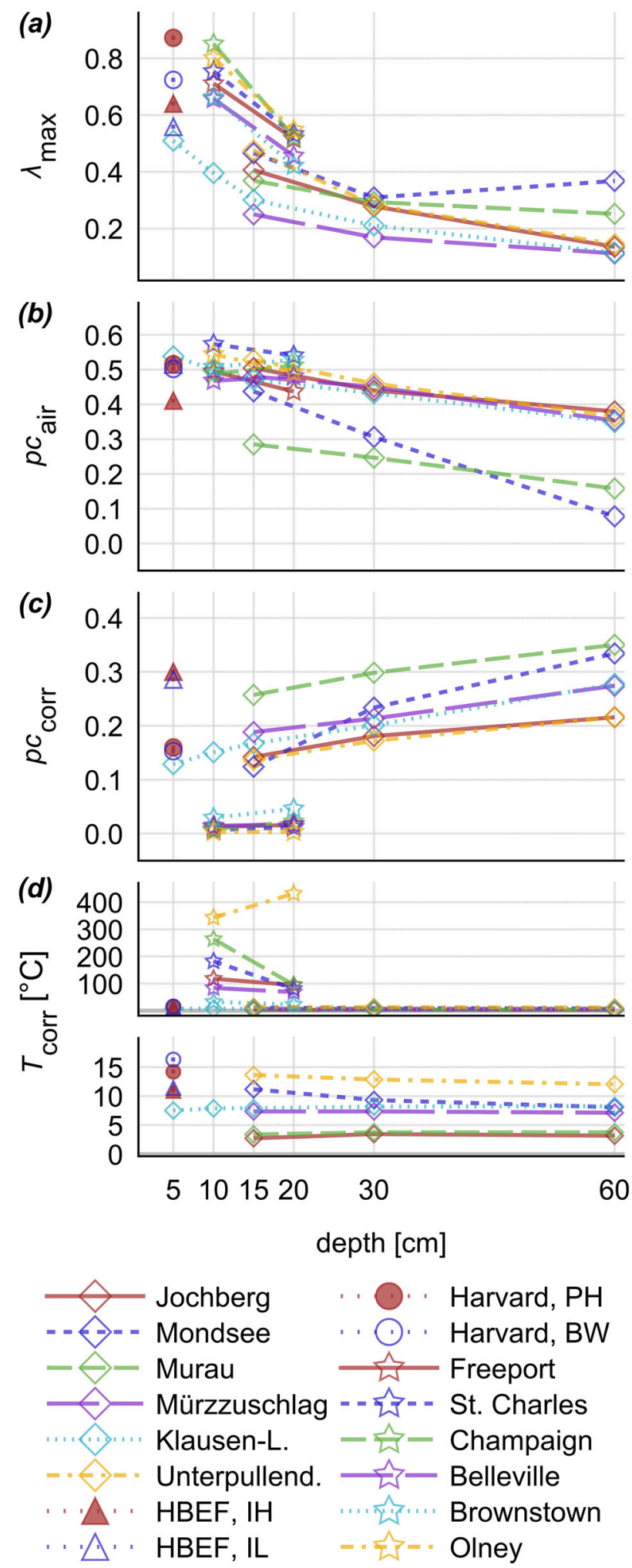

were strongly affected by certain site characteristics: $\lambda_{\max }$ values clearly decreased with increasing soil depth (Fig. 6a). Meaning, the time demand, to compensate a fraction of the temperature difference between soil layer and air, rose with increasing soil depth. Also the relative
४Fig. 6 Four selected parameters and their change with increasing soil depth. a Transfer coefficient values showed a clear decreasing trend with increasing soil temp. $\mathbf{b}$ Also the fraction of the air temperature in the calculation of the environmental temperature showed, almost linear, decrement. d Where the correction temperature on forested sites was in a close range to the annual mean air temperature, the open field locations (star symbol) revealed much higher values. On the other hand, the relative weighting (c) of these temperatures was much smaller on non-forested sites. It is assumed, that on these locations, both parameters combined compensate for direct shortwave radiation inputs

partition of the correction temperature $\left(p c_{\text {corr }}\right)$, in the calculation of the environmental temperature, increased in deeper soil layers (Fig. 6c). In contrast, the direct influence of air temperature $\left(p c_{\text {air }}\right)$ showed a decrease downwards.

Investigated open field sites differed strongly from forest sites, in parameter values of the correction temperature ( $\left.T_{\text {corr }}\right)$. Where on forest locations $T_{\text {corr }}$ resided closely to the stands annual mean air temperature, open field sites

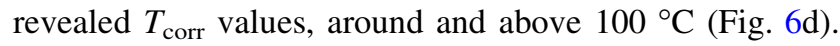
On the other hand, their relative weight $\left(p c_{\text {corr }}\right)$ in the calculation of the environmental temperature, is much lower than on forested sites. It is assumed, that in these cases, they correct for direct radiation energy inputs, which are obviously much higher without the presence of a shielding canopy. The reason that, even under such conditions, the simulator (which does not particularly address radiative heat flux) delivers good estimates of $T_{\text {soil }}$, might be found in the strong correlation between energy balance components, and the air temperature itself (Hock 2003).

\section{Conclusion}

The primary intention of this work was the provision of a tool, which enables the transformation of fragmentary records of forest soil temperature, into a complete time series of $T_{\text {soil }}$, using average daily air temperature as only input. In this specific case, the created time series is laying the base for the modeling of temperature dependent, biogeochemical soil processes.

To test the resilience of this model, it was applied to various locations and depths, covering a broad amplitude of site characteristics. The simulator delivered accurate predictions of the temperature of the topsoil, as well as of deeper layers. The high performance was not limited to the warm season. The combination of the insulating effect of the snow cover plus the effect of heat transformations at the freeze/thaw transition, on soil thermal regimes were captured sufficiently. The formulation was applied to forested, as well as open to field locations, where in the open field it failed to reproduce some major soil frost events. Bearing this limitation in mind, this simulator seems to be well applicable to other land use types. 
The model parameters lack a specific meaning in a strict physical sense. Therefore, currently the parameterization requires at least a modest amount of $T_{\text {soil }}$ observations, to yield sufficient results. A challenging impulse for future work, would be the attempt to derive model parameters, directly from more easily obtainable site characteristics. This also would enable the capability of the simulator to deal with a changing soil thermal regime, during stand development.

Acknowledgments This research was funded by the Austrian Science Fund (FWF, project number P23861-B16, granted to TW Berger) and the Commission for Interdisciplinary Ecological Studies (KIÖS) at the Austrian Academy of Sciences (project number 2010-05; granted to TW Berger). Level II data from Austrian sites was provided by the Austrian Research Centre for Forests. For the possibility to access air temperature data, we acknowledge the providers in the ECA\&D project.

$T_{\text {soil }}$ data from the HBEF were provided by Peter M. Groffman on 07/20/2015. We want to thank Jennifer L. Morse and Jorge Duran for their valuable field work. Air temperature records were provided by John Campbell and Amey Bailey on 07/20/2015. These data were gathered as part of the Hubbard Brook Ecosystem Study (HBES). The HBES is a collaborative effort at the Hubbard Brook Experimental Forest, which is operated and maintained by the USDA Forest Service, Northern Research Station, Newtown Square, PA. Significant funding for collection of these data was provided by the US National Science Foundation (Grants DEB 0949664-Ecosystem Studies, DEB 0423259 and DEB 1114804-Long-Term Ecological Research).

Further, we want to thank Jerry Melillo, Paul Steudler, Jacqueline Mohan, William Munger, Steven Wofsy, Emery Boose, Mark VanScoy, and all their collaborators, for the collection and the providing of air and soil temperature data, from the ecological research area at Harvard Forest.

Data from the open field sites, located in Illinois, were provided by the Water and Atmospheric Resources Monitoring Program, a part of the Illinois State Water Survey (ISWS) located in Champaign and Peoria, Illinois.

The Shuttle Radar Topography Mission, SRTM data product (Farr and Kobrick 2000) was retrieved from the online Data Pool, courtesy of the NASA Land Processes Distributed Active Archive Center (LP DAAC), USGS/Earth Resources Observation and Science (EROS) Center, Sioux Falls, South Dakota, https://lpdaac.usgs.gov/data_ access/data_pool.

At last, we thank Mathias Mayer for his encouraging words on writing this article, and for providing a valuable tip.

Open Access This article is distributed under the terms of the Creative Commons Attribution 4.0 International License (http://crea tivecommons.org/licenses/by/4.0/), which permits unrestricted use, distribution, and reproduction in any medium, provided you give appropriate credit to the original author(s) and the source, provide a link to the Creative Commons license, and indicate if changes were made.

\section{References}

Bailey AS, Hornbeck JW, Campbell JL, Eagar C (2003) Hydrometeorological database for Hubbard Brook Experimental Forest: 1955-2000, vol 305. US Department of Agriculture, Forest Service, Northeastern Research Station
Balisky AC, Burton PJ (1993) Distinction of soil thermal regimes under various experimental vegetation covers. Can J Soil Sci $73: 411-420$

Beltrami H (2001) On the relationship between ground temperature histories and meteorological records: a report on the Pomquet station. Glob Planet Change 29:327-348. doi:10.1016/S09218181(01)00098-4

Berbeco MR, Melillo JM, Orians CM (2012) Soil warming accelerates decomposition of fine woody debris. Plant Soil 356:405-417

Bergman TL, Incropera FP, Lavine AS (2011) Fundamentals of heat and mass transfer. Wiley

Betts AK, Ball JH, McCaughey JH (2001) Near-surface climate in the boreal forest. J Geophys Res Atmos 106:33529-33541. doi:10. 1029/2001jd900047

Bilgili M, Sahin B, Sangun L (2013) Estimating soil temperature using neighboring station data via multi-nonlinear regression and artificial neural network models. Environ Monit Assess 185:347-358. doi:10.1007/s10661-012-2557-5

Bond-Lamberty B, Wang CK, Gower ST (2005) Spatiotemporal measurement and modeling of stand-level boreal forest soil temperatures. Agric For Meteorol 131:27-40. doi:10.1016/j. agrformet.2005.04.008

Boose E (2001) Fisher meteorological station (since 2001). Harvard Forest Data Archive: HF001

Brown SE, Pregitzer KS, Reed DD, Burton AJ (2000) Predicting daily mean soil temperature from daily mean air temperature in four northern hardwood forest stands. For Sci 46:297-301

Butler SM, Melillo JM, Johnson JE, Mohan J, Steudler PA, Lux H, Burrows E, Smith RM, Vario CL, Scott L (2012) Soil warming alters nitrogen cycling in a New England forest: implications for ecosystem function and structure. Oecologia 168:819-828

Campbell JL, Mitchell MJ, Groffman PM, Christenson LM, Hardy JP (2005) Winter in northeastern North America: a critical period for ecological processes. Front Ecol Environ 3:314-322. doi:10.1890/1540-9295(2005)003[0314:Winnaa]2.0.Co;2

Campbell JL, Ollinger SV, Flerchinger GN, Wicklein H, Hayhoe K, Bailey AS (2010) Past and projected future changes in snowpack and soil frost at the Hubbard Brook Experimental Forest, New Hampshire, USA. Hydrol Process 24:2465-2480. doi:10.1002/ hyp.7666

Changnon SA, Angel JR, Kunkel KE, Lehmann CM (2008) Illinois Climate Atlas. Illinois State Water Survey. Prairie Research Institute of the University of Illinois, Urbana-Champaign

Davidson EA, Janssens IA, Luo YQ (2006) On the variability of respiration in terrestrial ecosystems: moving beyond $\mathrm{Q}(10)$. Glob Change Biol 12:154-164. doi:10.1111/j.1365-2486.2005.01065.x

Duran J, Morse JL, Groffman PM, Campbell JL, Christenson LM, Driscoll CT, Fahey TJ, Fisk MC, Mitchell MJ, Templer PH (2014) Winter climate change affects growing-season soil microbial biomass and activity in northern hardwood forests. Glob Change Biol 20:3568-3577. doi:10.1111/gcb.12624

Farr TG, Kobrick M (2000) Shuttle Radar Topography Mission produces a wealth of data. Eos Trans AGU 81:583

Gehrig-Fasel J, Guisan A, Zimmermann NE (2008) Evaluating thermal treeline indicators based on air and soil temperature using an air-to-soil temperature transfer model. Ecol Model 213:345-355. doi:10.1016/j.ecolmodel.2008.01.003

Hock R (2003) Temperature index melt modelling in mountain areas. J Hydrol 282:104-115. doi:10.1016/S0022-1694(03)00257-9

Hollinger SE, Reineke BC, Peppler RA (1994) Illinois climate network: site descriptions, instrumentation, and data management, vol 178. Illinois State Water Survey

$\mathrm{Hu}$ Q, Feng S (2003) A daily soil temperature dataset and soil temperature climatology of the contiguous United States. J Appl Meteorol 42:1139-1156. doi:10.1175/1520-0450(2003)042 $<1139$ :Adstda $>2.0$. Co; 2 
Kang S, Kim S, Oh S, Lee D (2000) Predicting spatial and temporal patterns of soil temperature based on topography, surface cover and air temperature. For Ecol Manag 136:173-184. doi:10.1016/ S0378-1127(99)00290-X

Katterer T, Andren O (2009) Predicting daily soil temperature profiles in arable soils in cold temperate regions from air temperature and leaf area index. Acta Agr Scand B-S P 59:77-86 doi:10.1080/ 09064710801920321

Kim S, Singh VP (2014) Modeling daily soil temperature using datadriven models and spatial distribution. Theor Appl Climatol 118:465-479. doi:10.1007/s00704-013-1065-z

Kirkpatrick S, Gelatt CD, Vecchi MP (1983) Optimization by simulated annealing. Science 220:671-680. doi:10.1126/ science.220.4598.671

Kisi O, Tombul M, Kermani MZ (2015) Modeling soil temperatures at different depths by using three different neural computing techniques. Theor Appl Climatol 121:377-387. doi:10.1007/ s00704-014-1232-x

Körner C, Paulsen J (2004) A world-wide study of high altitude treeline temperatures. J Biogeogr 31:713-732

Lei SG, Daniels JL, Bian ZF, Wainaina N (2011) Improved soil temperature modeling. Environ Earth Sci 62:1123-1130. doi:10. 1007/s12665-010-0600-9

Macdonald NW, Zak DR, Pregitzer KS (1995) Temperature effects on kinetics of microbial respiration and net nitrogen and sulfur mineralization. Soil Sci Soc Am J 59:233-240

Melillo J, Steudler P, Mohan J (1999) Prospect hill soil warming experiment at Harvard forest since 1991. Harvard Forest Data Archive: HF005. doi:10.6073/pasta/246c9bf827daa3a61d6a6dfb 6b393b32

Melillo JM, Steudler PA, Aber JD, Newkirk K, Lux H, Bowles FP, Catricala C, Magill A, Ahrens T, Morrisseau S (2002) Soil warming and carbon-cycle feedbacks to the climate system. Science 298:2173-2176

Melillo J, Steudler P, Mohan J (2003) Barre woods soil warming experiment at Harvard forest since 2001. Harvard Forest Data Archive: HF018. doi:10.6073/pasta/dbb1bac50540a22cfdd6cd $9 \mathrm{a} 817274 \mathrm{fd}$

Menne MJ, Durre I, Korzeniewski B, McNeal S, Thomas K, Yin X, Anthony S, Ray R, Vose RS, Gleason BE, Houston TG (2012a) Global historical climatology network-daily (GHCN-Daily), Version 3. NOAA National Climatic Data Center. doi:10.7289/ V5D21VHZ

Neumann M, Schnabel G, Gärtner M, Starlinger F, Fürst A, Mutsch F, Englisch M, Smidt S, Jandl R, Gartner K (2001) Waldzustandsmonitoring in Österreich: Ergebnisse der Intensivbeobachtungsflächen (Level II). Forstliche Bundesversuchsanstalt Wien
Tank AMGK et al (2002) Daily dataset of 20th-century surface air temperature and precipitation series for the European Climate Assessment. Int J Climatol 22:1441-1453. doi:10.1002/joc.773

Menne MJ, Durre I, Vose RS, Gleason BE, Houston TG (2012) An overview of the global historical climatology network-daily database. J Atmos Ocean Technol 29:897-910. doi:10.1175/ Jtech-D-11-00103.1

Mucina L, Grabherr G, Ellmauer T (1993) Die Pflanzengesellschaften Österreichs. Teil 3: Wälder und Gebüsche. Gustav-Fischer, Jena, Stuttgart, New York

Munger W, Wofsy S (1999) Canopy-atmosphere exchange of carbon, water and energy at Harvard forest EMS tower since 1991. Harvard Forest Data Archive: HF004. doi:10.6073/pasta/ e89d6b8d2b175400e3072902e52280a1

Nash JE, Sutcliffe JV (1970) River flow forecasting through conceptual models part I-a discussion of principles. J Hydrol 10:282-290

Paul KI, Polglase PJ, Smethurst PJ, O'Connell AM, Carlyle CJ, Khanna PK (2004) Soil temperature under forests: a simple model for predicting soil temperature under a range of forest types. Agric For Meteorol 121:167-182. doi:10.1016/j.agrfor met.2003.08.030

Rankinen K, Karvonen T, Butterfield D (2004) A simple model for predicting soil temperature in snow-covered and seasonally frozen soil: model description and testing. Hydrol Earth Syst Sci 8:706-716

Svensson M, Jansson PE, Gustafsson D, Kleja DB, Langvall O, Lindroth A (2008) Bayesian calibration of a model describing carbon, water and heat fluxes for a Swedish boreal forest stand. Ecol Model 213:331-344. doi:10.1016/j.ecolmodel.2008.01.001

Talaee PH (2014) Daily soil temperature modeling using neuro-fuzzy approach. Theor Appl Climatol 118:481-489. doi:10.1007/ s00704-013-1084-9

Viterbo P, Beljaars A, Mahfouf JF, Teixeira J (1999) The representation of soil moisture freezing and its impact on the stable boundary layer. Q J Roy Meteor Soc 125:2401-2426. doi:10.1256/Smsqj.55903

Wagle P, Kakani VG (2014) Confounding effects of soil moisture on the relationship between ecosystem respiration and soil temperature in switchgrass. Bioenerg Res 7:789-798. doi:10.1007/ s12155-014-9434-8

Zheng D, Hunt ER Jr, Running SW (1993) A daily soil temperature model based on air temperature and precipitation for continental applications. Clim Res 2:183-191 